\title{
Policing the voluntary carbon market
}

\author{
MICHAEL GILLENWATER ${ }^{1,2,}$, DERIK BROEKHOFF ${ }^{3}$, MARK TREXLER $^{4}$, JASMINE HYMAN $^{5}$ \\ AND ROB FOWLER ${ }^{6}$
}

\section{Voluntary greenhouse-gas emission offset markets are in need of government oversight.}

N umerous opinion polls have indicated that concern over global climate change has risen dramatically in the US and elsewhere ${ }^{1,2,3}$. One tangible measure of this growing concern has been the emergence of voluntary greenhousegas (GHG) offset markets, in which businesses and consumers purchase GHG reductions instead of directly reducing their own emissions ${ }^{4}$.

A GHG 'offset' is an intangible economic commodity that represents the avoidance or sequestration of GHG emissions. GHG offsets are derived from distinct projects, involving anything from low-carbon energy production, to energy efficiency measures, the destruction of GHGs such as methane and nitrous oxide, and tree planting and soil carbon enhancement activities. Offsets offer buyers a potentially lower-cost alternative to reducing their own emissions (Fig. 1). The geographic source of GHG emissions is irrelevant to their climate change impact. Therefore, GHG emission reductions are a global, rather than local, public good and can be traded in a global market ${ }^{5}$.

Although currently small in comparison to regulated offset markets under the Kyoto Protocol, voluntary offset markets are growing rapidly (Table 1), especially in the United States, and could expand tenfold by $2010^{6}$. Even the US House of Representatives is preparing to enter the voluntary offset market as a buyer under its Green Capital Initiative? ${ }^{7}$.

The purchase of GHG offsets is economically rational in cases where reducing emissions attributable to one's own activities is more costly. Paying someone else to pollute less may be wiser - both for the purchaser and for society as a whole - than reducing pollution oneself because more emissions can be reduced for a given expenditure of resources. The atmosphere benefits to the extent that an offset reduction

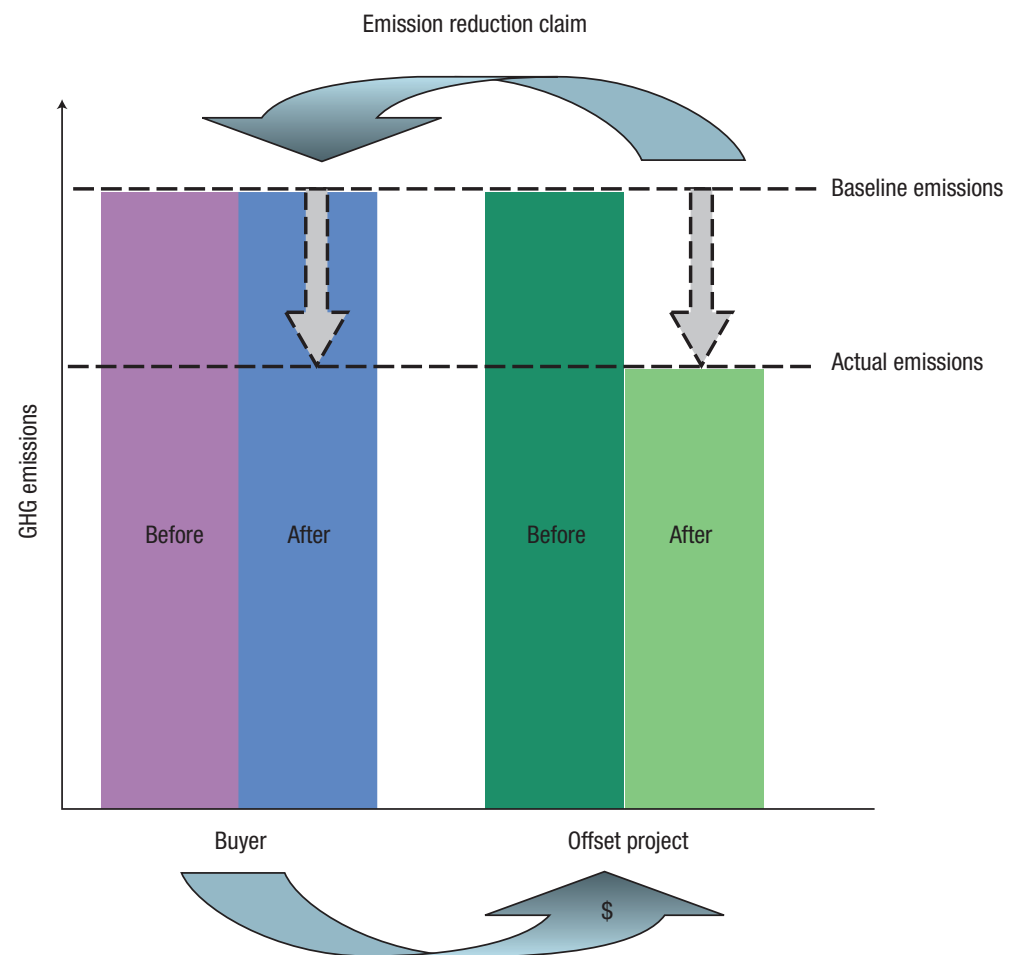

Figure $1 \mathrm{GHG}$ offset transaction.

is equivalent to an emission reduction made directly by the purchaser. Recently, however, offsets have been widely criticized in the media as to whether they represent real emission reductions $\mathrm{s}^{8,9,10,11}$.

GHG offset transactions face three fundamental challenges. First, a common and credible procedure is necessary for selecting emission reduction projects made possible by offset credit sales and for quantifying the reductions achieved against a business-as-usual (BAU) baseline in which no specific actions are taken to reduce GHG emissions. Second, credible monitoring is needed to verify that reductions actually occur as claimed. Third, unambiguous property rights over emission reduction credits are essential for markets to operate effectively.

These challenges are not unique to offset markets, but they are symptomatic of markets that trade in commodities representing public goods. Such markets do not arise naturally or function efficiently without assigned property rights, rules governing transactions, and oversight ${ }^{12}$. Consumers need credible information on the quality of what they are purchasing. Similar problems exist with the development of product standards, such as for organic 
food or sustainable forest products. For voluntary GHG offsets, commonly accepted definitions of quality are currently lacking. Although GHG offset markets appear to be expanding on their own, there is a serious risk of their collapse due to a lack of standards, policing and credibility.

What has proven most vexing for those involved in GHG offset markets is defining 'additionality'. This is a key factor determining a project's eligibility to sell credits. The crucial question is whether the added revenue or other resources gained from selling GHG offset credits somehow enables a project's implementation, or if the extra revenue simply lines the pockets of those who would have implemented the project anyway? In markets for public goods that lack some form of mandated quotas (for example, emission caps), additionality determinations serve the function of maintaining scarcity in the marketplace. Without them, GHG offsets representing business-as-usual reductions will tend to flood the market.

There is no correct technique for determining additionality because it involves the evaluation of counterfactual circumstances. No test for additionality can provide certainty about what would have happened otherwise. The challenge is akin to statistical hypothesis testing. Adopt tests that are too stringent and one risks disqualifying many truly additional projects, thus restricting offset supplies and increasing their prices. But adopt tests that are too lenient, and the market will be dominated by 'free riders' who would have implemented their projects anyway.

Adding to this challenge is the fact that the appropriate set of additionality tests varies from one type of project to another. For projects that involve flaring of methane from landfills, for example, excluding projects that are required by law or regulation may be sufficient to ensure that the majority of projects are additional. But for some energy-efficiency or renewableenergy projects, such as investments in wind turbines, more thorough tests are needed to differentiate additional from BAU projects. The solution to additionality lies in adopting tests that will achieve a balance of 'false negatives' (that is, truly additional projects mistakenly classified as business-as-usual) and 'false positives' (that is, BAU projects classified as additional $)^{13}$. One of the key problems with voluntary GHG offsets is that no central authority exists to manage this balance across the entire market

A second challenge for GHG offsets has to do with monitoring and verification to assure that offsets are being achieved in the manner and quantity promised. Generally, independent third-party

\begin{tabular}{|c|c|c|}
\hline & $\begin{array}{l}2006 \text { volume } \\
\text { (million tons } \mathrm{CO}_{2} \text { equivalents) }\end{array}$ & $\begin{array}{l}2006 \text { value } \\
\text { (US\$ million) }\end{array}$ \\
\hline \multicolumn{3}{|l|}{ GHG offset market } \\
\hline Total Voluntary Market & 23.7 & 91 \\
\hline Voluntary 0TC* & 13.4 & 54.9 \\
\hline Chicago Climate Exchange $^{\dagger}$ & 10.3 & 36.1 \\
\hline \multicolumn{3}{|l|}{ Other GHG trading schemes } \\
\hline EU Emissions Trading Scheme ${ }^{\ddagger}$ & 1,101 & 24,357 \\
\hline Clean Development Mechanism & 475 & 5,257 \\
\hline
\end{tabular}

verification of offset projects against a common standard is necessary for consumers to have a reliable and unbiased source of information on offset quality. Analogously, we do not expect consumers of organic food to monitor the farming practices of their food suppliers. Yet, for voluntary carbon offsets, there is no agreed standard for monitoring methods or the appropriate frequency and requirements for verification. Determining appropriate monitoring and verification standards requires balancing costs - which, if too high, might drive away more cost-effective projects - with the need for environmental integrity.

Finally, GHG offsets face the challenge of determining ownership of a particular emission reduction. Ownership of offset credits is relatively unambiguous in some cases, but in other cases it is fraught with complications. For example, the rights to make specific environmental claims are often disputed with energyefficiency or renewable-energy projects where investors, equipment suppliers, utilities and electricity customers are all involved. Legal mechanisms are not yet in place to disallow two parties from selling the same reduction or to prevent a single party from selling a reduction to multiple buyers. Consistent rules that will promote investment and market efficiency are needed, as well as registries to foster transparency of transactions and track the retirement of offsets used to make emission reduction claims.

A number of organizations involved in the voluntary offset market are developing standards in an attempt to address these challenges. But it is not clear if any of these standards will gain market acceptance or have the ability to police the practices of market participants. To date, none of them has adequately addressed all three of the aforementioned challenges for establishing a true offset 'commodity' (that is, project eligibility, monitoring and verification procedures, and enforcement of ownership) ${ }^{14}$. Although the consequences are difficult to predict, the confusion produced by a host of independent 'standards' operating in a regulatory vacuum has the potential to discredit market-based environmental policies with the public as a means of addressing climate change.

Environmental commodity markets are inherently more susceptible to market failures than traditional markets because the commodity transacted is both intangible and represents a public good. Where buyers cannot easily evaluate the quality of a good or service, there is a clear need for quality assurance mechanisms. Without such mechanisms, competitive pressures force sellers to minimize quality and limit transparency. The result will be that bad projects will drive good projects out of the market.

Some governments are beginning to respond to the need for oversight of these voluntary markets. In January 2007, the UK's Department of Environment and Rural Affairs drafted a code of best practice for the voluntary GHG offset market ${ }^{15}$, and in July 2007, the Australian government announced that it would provide a government-administered program for businesses and households to become 'carbon neutral' via approved offsets ${ }^{16,17}$.

Although government intervention is no guarantee that the challenges discussed above will be effectively addressed, we find these efforts laudable, and call on the US and other governments to follow the example of the UK and Australia by setting standards and overseeing the voluntary GHG offset marketplace. Specifically, governments should initially develop best-practice guidelines that address the three key challenges described above.

These voluntary guidelines should immediately be followed by a more thorough process of standard setting, with a board to approve project eligibility criteria, accounting methodologies, as well as monitoring, registration and public reporting requirements. Ideally, governments should build off the existing work under the United Nation's Framework Convention on Climate 
Change and its Clean Development Mechanism ${ }^{18}$ (which allows developed countries to invest in projects that reduce emissions in developing countries as an alternative to more expensive emission reductions in their own countries), New South Wales' Greenhouse Gas Reduction Scheme ${ }^{19}$ (which requires electricity retailers and other parties to meet mandatory targets for reducing or offsetting their emissions from the electricity they supply or use), and existing non-governmental organization efforts $^{20}$. Furthermore, they should cooperate in their standard setting processes to harmonize rules and create a globally-recognized and homogeneous GHG offset commodity for voluntary markets. The US Department of Agriculture has developed a similar process of bilateral cross-recognitions of standards for organic food labels that may serve as a useful model.

Ultimately, mandatory government policy must be our primary approach to dealing with climate change and the GHG emissions that cause it. However, voluntary GHG offset markets can contribute to emissions mitigation and sustainable development objectives while government-mandated schemes are under development. Voluntary markets can also foster innovation through new technologies and project types still under evaluation by compliance emission markets. While governments focus on developing a consensus on GHG mitigation policies, or more stringent policies, the voluntary offset market, with proper government oversight, has the potential to play a significant role in mitigating future climate change.

\footnotetext{
References

1. Bannon, B. et al. Americans' Evaluations of Policies to Reduce Greenhouse Gas Emissions (New Scientist Magazine, Resources for the Future, Stanford University, 2007); http://media. newscientist.com/data/images/ns/av/global_warming_poll_ stanford.pdf

2. http://sequestration.mit.edu/research/survey2006.htm

3. http://www.globescan.com/news_archives/csr_climatechange.html

4. Hamilton, K. et al. State of the Voluntary Carbon Market 2007: Picking Up Steam (EcoSystem Marketplace and New Carbon Finance, 2007); http://ecosystemmarketplace.com/documents/ acrobat/StateoftheVoluntaryCarbonMarket17July.pdf

5. Jacobs, M. The Green Economy (Pluto, London, 1991).

6. http://www.icfi.com/Newsroom/carbon-offsets-2006.asp

7. http://speaker.gov/issues?id $=0023$
}

8. Revkin, A. Carbon-neutral is hip, but is it green? New York Times, April 292007.

9. Harvey, F. \& Fidler, S. Industry caught in carbon 'smokescreen' Financial Times, April 252007

10. Carbon offsets: Sins of emission. The Economist, August 14 2006. Nature 444, 976-977 (2006).

11. Neumayer, E., Weak versus Strong Sustainability (Edward Elgar Publishing, Cheltenham, 2003).

12. Trexler, M. C. et al. Sustainable Development Law \& Policy VI (2), 30 (2006).

13. Broekhoff, D. Linking Markets for GHG Reductions: Can It Be Done? (International Network for Environmental Compliance and Enforcement, 2007); http://www.inece.org/emissions/ dublin/Broekhoff.pdf

14. DEFRA Establishing a voluntary code of best practice for the provision of carbon offsetting to UK customers; http://www.defra gov.uk/corporate/consult/carbonoffsetting-cop/index.htm

15. http://www.house.gov/apps/list/press/global_warming/ July18offsetFTC.shtml 16. http://www.greenhouse.gov. au/greenhousefriendly/index.html

17. http://cdm.unfccc.int/

18. http://www.greenhousegas.nsw.gov.au

19. Broekhoff, D. Voluntary Carbon Offsets - Getting What You Paid For (World Resources Institute, 2007); http://pdf.wri. org/20070718_broekhoff_testimony.pdf

${ }^{1}$ Princeton University; ${ }^{2}$ Greenhouse Gas Experts Network; ${ }^{3}$ World Resources Institute; ${ }^{4}$ EcoSecurities; ${ }^{5}$ The Gold Standard; ${ }^{6}$ Abatement Solutions - Asia Pacific *e-mail:gillenwater@alum.mit.edu

\section{Nature Publishing Group journals Covering the physical sciences spectrum}

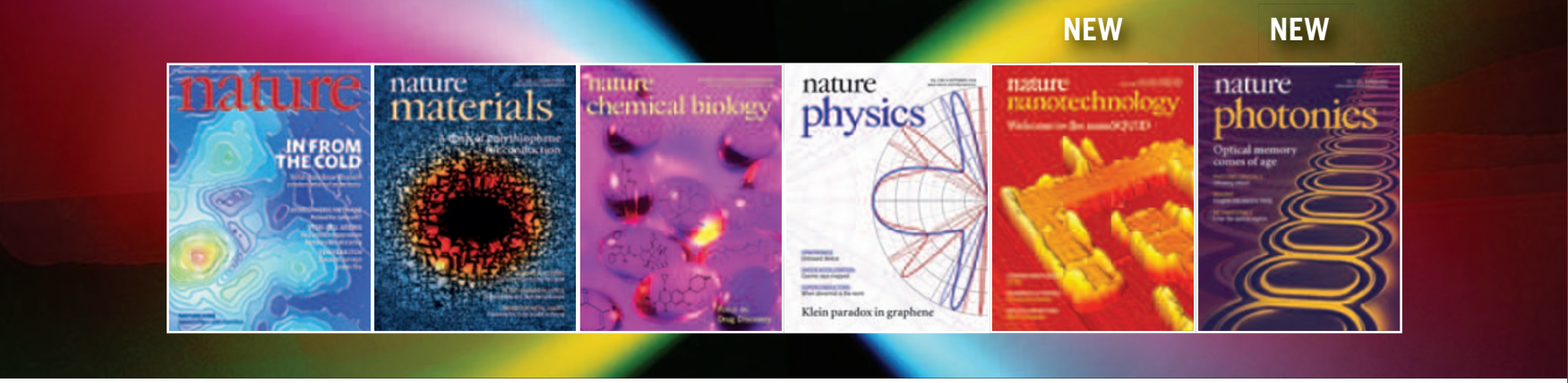

Nature Publishing Group offers a range of journals in the physical sciences - from the broad scope of Nature to specific titles in physics, materials and chemical biology, and new titles in nanotechnology and photonics.

Each journal carries a mix of research papers, review titles, news and views, and commentaries, that will keep you up-todate with the latest research in your area.

Nature Publishing Group's physical science journals are available through personal subscription, institutional print subscription, and site licences. Visit www.nature.com to subscribe today. 